\title{
Fossil Weathering and Preparation Mimic Soft Tissues in Eocrinoid and Somasteroid Echinoderms from the Lower Ordovician of Morocco
}

\section{Farid Saleh ${ }^{1, *}$, Bertrand Lefebvre', Aaron W. Hunter, ${ }^{2}$ and Martina Nohejlová ${ }^{1,3}$}

${ }^{1}$ Univ. Lyon, Université Claude Bernard Lyon 1, ENS de Lyon, CNRS, UMR 5276 Laboratoire de Géologie de Lyon: Terre, Planètes, Environnement, F-69622 Villeurbanne, France

${ }^{2}$ Department of Earth Sciences, University of Cambridge, Downing Street, Cambridge CB2 3EQ UK

${ }^{3}$ Czech Geological Survey, Klárov 3, Praha 1, 11821 Czech Republic

*farid.saleh@univ-lyon1.fr

\begin{abstract}
Investigation of the Fezouata Shale has added to our knowledge on the initial diversification of metazoans. These Lower Ordovician deposits yielded abundant and diverse remains of cuticularized to lightly sclerotized organisms, in addition to numerous soft tissues. Described fossilized soft parts recovered from the Fezouata Shale belong mainly to arthropods. Soft tissues in echinoderms, a main component of the Fezouata Biota, remain largely unexplored. Here, we show that soft tissue-like impressions previously reported in eocrinoid and somasteroid echinoderms from this formation, are the results of modern weathering and fossil preparation that involved the use of latex molds: they do not reflect any original (soft) anatomical features of these organisms. These two examples suggest that reports of putative soft parts, especially in taxa with no current representatives, need to be thoroughly and critically evaluated.
\end{abstract}

Keywords: Echinoderms, Exceptional Preservation, Fezouata Lagerstätte, Morocco, Ordovician, SEM, X-ray fluorescence maps

\section{Introduction}

Exceptional fossil preservation consists of the preservation of non-biomineralized soft parts (for example, digestive and nervous systems of animals) in the geological record. Fossiliferous localities showing this type of preservation are called Konservat-Lagerstätten. The late Tremadocian Fezouata Shale in the Anti-Atlas of Morroco, deposited approximately 480 million years ago, is the only Ordovician period Konservat-Lagerstätte to yield a fully marine diverse exceptionally preserved fauna [1]. The $\sim 900$ meter thick siltstones of the Fezouata Shale have yielded over 200 taxa of marine invertebrates [2]. Most of them belong to arthropods and echinoderms $[2,3]$. In these deposits, exceptionally preserved soft parts (for example, guts) are well-documented in various groups of arthropods (for example, anomalocaridids, trilobites) [1,2,4,5], annelids [6], hyolithids [7], molluscs [8], and palaeoscolecid worms [9,10].

In marked contrast, very few occurrences of exceptionally preserved soft parts have been reported from Fezouata echinoderms: a putative gut was mentioned in one specimen of solutan [11], and more abundant remains (water-vascular system, gut) were described in stylophorans [12]. The watervascular (or ambulacral) system is a complex, non-biomineralized, coelomic, hydraulic structure, which is unique to echinoderms. It consists of ambulacral canals leading to lateral sets of smaller tube feet, which are used for feeding, locomotion, and respiration.

Such a rarity of exceptionally preserved soft parts in echinoderms from the Fezouata Shale is not surprising. In spite of some recent spectacular reports, for example, in the Silurian
Herefordshire Lagerstätte, UK $[13,14,15]$ or the Devonian Hunsrück Slate, Germany [16], very few examples of soft parts have been described in fossil echinoderms. This situation mainly results from the fast post-mortem disarticulation of their multi-element calcite skeleton and, hence, their low preservation potential, [3,17]. Experimental taphonomy, the study of how organisms decay and become fossilized, on modern echinoderms suggests that both skeletal elements and soft parts disarticulate and degrade within a few days after death [18]. Consequently, due to taphonomic biases [19], the preservation of complete echinoderm specimens yielding soft tissues is extremely rare even within Lagerstätten. Because of these biases, understanding the preservational pathway of an organism is vital prior to any paleontological description especially for animal groups with no current representatives. In this study, we aim at understanding the preservation of eocrinoids and somasteroids from the Fezouata Shale [20,21] and critically evaluate the recent reports of putative soft tissues (watervascular system) in these two groups.

\section{Material and Methods}

The taphonomy of soft parts was analyzed in the two best-preserved specimens of eocrinoid and somasteroid echinoderms from the Fezouata Shale [20,21]. This material is deposited in the paleontological collections of the Musée des Confluences, Lyon, France (acronym "ML"), and Claude Bernard Lyon 1 University, Villeurbanne, France (acronym "UCBL-FSL"), respectively. The eocrinoid specimen (ML20269159, Reboul collection) was collected at Bou Izargane, about $18 \mathrm{~km}$ north of Zagora, Morocco. This locality is a well-known fossiliferous site, where abundant and diverse late Tremadocian exceptionally preserved fossils have been collected (for example, anomalocaridids, marrellomorphs, palaeoscolecids), including trilobites and stylophoran echinoderms with soft parts $[5,12,22]$. The somasteroid specimen (UCBL-FSL 424962 , Vizcaïno collection) is from an unknown locality, probably late Tremadocian in age, from the Ternata plain, north of Zagora, Morocco.

The two specimens were characterized using a FEI Quanta 250 scanning electron microscope (SEM) equipped with a backscattered electron detector in addition to an energydispersive X-ray analyzer (EDX) at accelerating voltages that varied from 5 to $15 \mathrm{kV}$. The backscattered electron detector allowed the acquisition of images with dark pixels corresponding to light elements (that is, small atomic number Z) 


\section{hor BA Scientific}

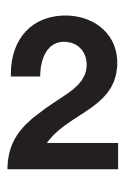

NEW

Innovative

Microscopy

Products

from $\mathrm{HOR} \mid \mathrm{BA}$

Applications like

FLIM, TRPL,

photoluminescence,

Raman and

electroluminescence

require more

capabilities than your microscope can provide.

HORIBA has two new

products to help you

multitask your microscope.

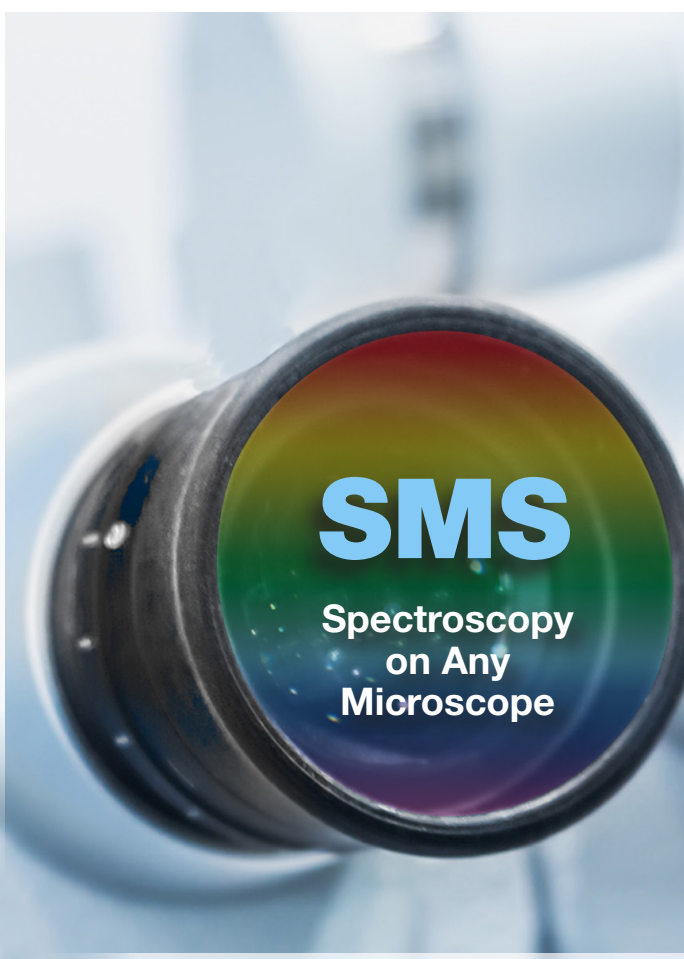

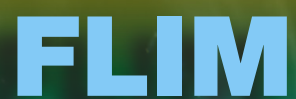

Video Rate FLIM
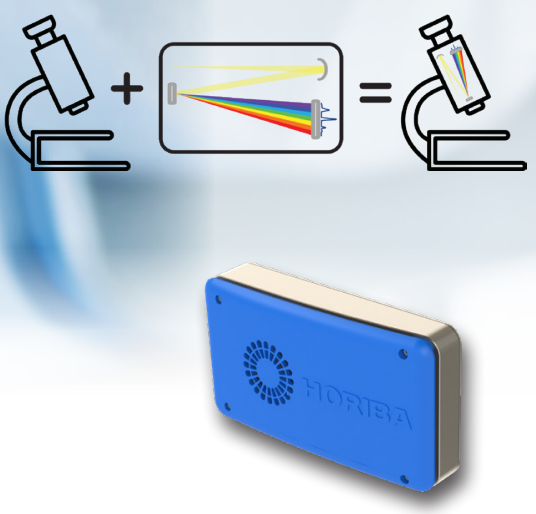

NEW Standard Microscope Systems

Add various spectroscopies to

ANY STANDARD Microscope

without sacrificing performance of either one!

\section{NEW SPAD FLIMera Camera}

Fluorescence lifetime images from

25K simultaneous pixel measurements

at a video rate of 30 frames per second!
See us at $\begin{aligned} & \text { - Photonics West - booth \#1726 } \\ & \text { - BiOS - booth \#8156 } \\ & \text { - Biophysical - booth \#409 }\end{aligned}$

Find out more at: horiba.com/microscopy
ELEMENTAL ANALYSIS

FLUORESHENIGE

HAATILES \& OEMI SPEGTROMEIERS

OPTICAL COMPONENTS

GUSTOM SOLUTIONS

PARTIGLE GHARAGTERIZATION

RAMAN / AFM-RAMAW / TERS

SPEGTROSCOPIC ELLIPSOMETRY 
and white pixels corresponding to spots with heavy elements (that is, high atomic number Z). The EDX allowed, at low voltages, optimized acquisition of spectra revealing the distribution of light elements (that is, carbon). At high voltages, heavy elements, such as iron, were detected. In addition, X-ray fluorescence (XRF) elemental maps of these two specimens were obtained using a Bruker M4 Tornado micro-XRF instrument operating under vacuum at $50 \mathrm{kV}$ and $600 \mu \mathrm{A}$.

As both specimens were not completely flattened it was difficult to assess if negative elemental results were due to the actual absence of elements in the analyzed spot, or if the negative results were due to a topographic effect that inhibited the beam from reaching the spot. For this reason general elemental maps of rhodium $\mathrm{Rh}$, the source of the XRF machine, were made. When Rh signal was absent it indicated that topographical effects prevented the beam from reaching the spot. Presence of $\mathrm{Rh}$ implied that the beam did reach the surface and the absence of an element was due to actual absence of this element from the chemical composition of the analyzed area. evidenced in stylophoran echinoderms from the Fezouata Shale [12]. However, both the elemental and mineralogical signatures are different in these three occurrences.

Soft parts in exceptionally preserved fossils from the Fezouata Shale are preserved in both euhedral and framboidal pyrite [23]. These mineralogical morphologies are indicative of an early authigenic pyritization that occurred under anoxic conditions at time of burial [24], replicating soft tissues that are the most prone to decay [25]. After that, pyrite was transformed due to recent weathering to iron oxides $[12,23]$. This situation was observed in the soft parts reported in the stylophoran material from Bou Izargane in Morocco [12].

In contrast, the near absence of both euhedral and framboid minerals in the eocrinoid specimen indicates that ironrich minerals that are found in this fossil are not the result of the combined activity of authigenic mineralization and recent weathering. In this fossil, the iron oxides are simply related to the activity of recent weathering and, thus, they do not replicate any original anatomy. The distribution of these Fe-rich minerals

\section{Results}

The eocrinoid specimen (Figure 1A) is entirely preserved in iron $(\mathrm{Fe})$, which is shown by the green fluorescence in Figure $1 \mathrm{C}$ and the SEM EDX map in Figure 1E. This contrasts with the matrix, which is rich in silicon $(\mathrm{Si})$ as shown by the red fluorescence in Figure 1B and the SEM EDX map in Figure 1E. Some Ferich small and repetitive structures are present within the brachioles (skeletonized arm-like feeding appendages) (Figure 1D). Most of the Fe-rich areas are preserved in small iron crystals that do not have any specific shape (that is, star-like minerals that are not euhedral nor framboidal; Figures 2A-D).

The somasteroid specimen (Figure 3A) is preserved as an imprint in the rock, and it shows the same elemental signature as the matrix, which is rich in Si (Figure 3B). However, some areas of the fossil appear to be depleted in Si (Figure 3B). Rh distribution shows that some of these anomalies are due to the actual absence of $\mathrm{Si}$ (that is, when $\mathrm{Rh}$ is present $\mathrm{Rh}+$; Figure 3C), while the absence of $\mathrm{Si}$ in other regions is simply due to a hidden zone that was not analyzed by the beam (that is, Rh-; Figure 3C). The $\mathrm{Rh}+$ zones are rich in carbon that is mostly detected when analyzing the specimen at $5 \mathrm{kV}$ (Figure 3D). The carbon shows a repetitive pattern of small identical structures along the arms of the somasteroid (Figures 4A-B). However, carbon is also present elsewhere in the specimen (Figures $4 \mathrm{C}-\mathrm{F}$ ).

\section{Interpretation and Discussion}

The structures found in both the eocrinoid (Figure 1D) and somasteroid (Figures $4 \mathrm{~B}-\mathrm{C}$ ) specimens resemble tube feet of the water vascular system, as, for example, those
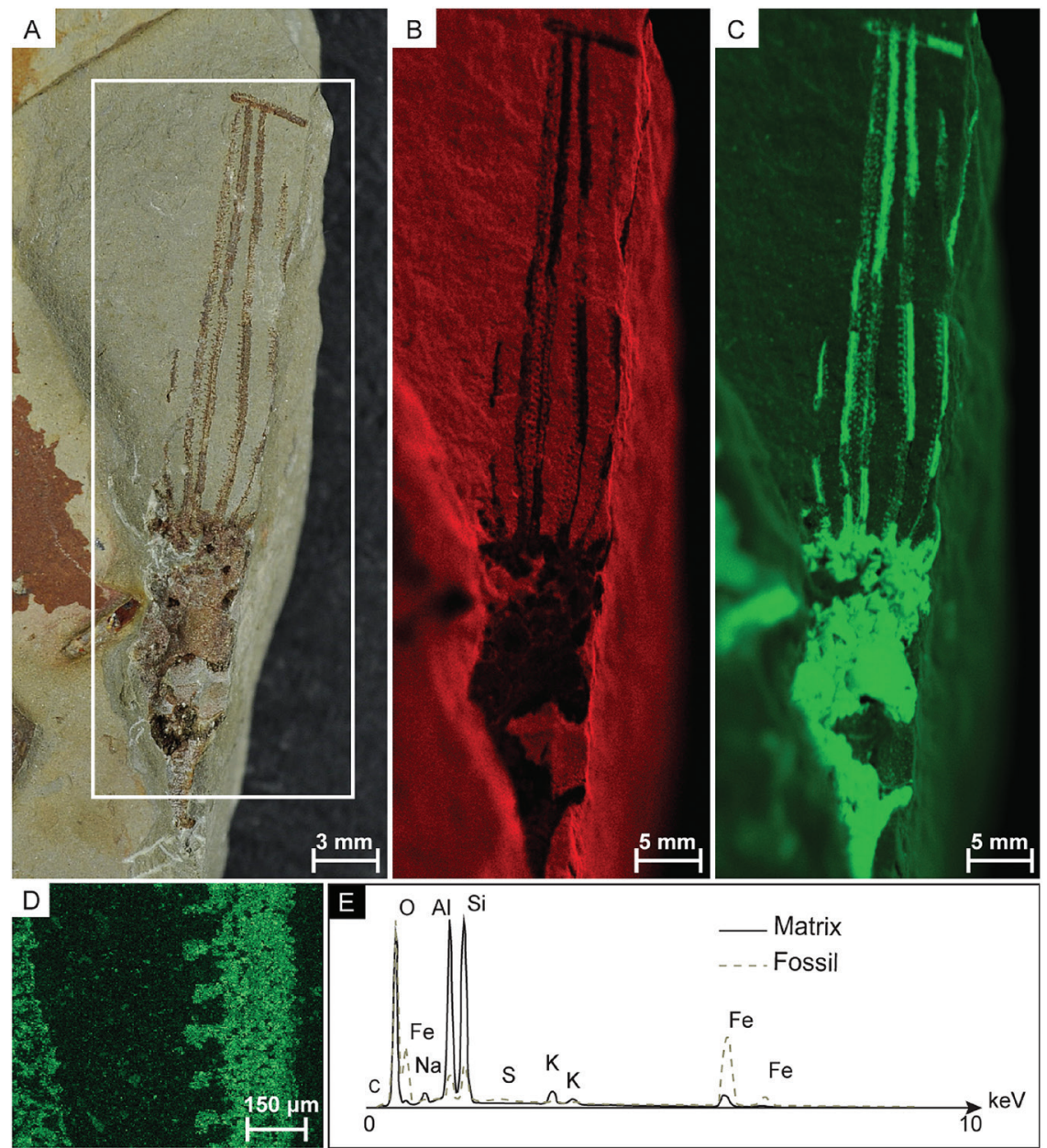

Figure 1: Analyzed specimen of eocrinoid echinoderm, late Tremadocian, Fezouata Shale, Bou Izargane, Zagora area, Morocco; ML20-269159. (A) Photograph of the specimen; (B) X-ray fluorescence image of inset shown in Figure 1A. Red indicates a high concentration of silicon distribution; (C) X-ray fluorescence of iron distribution (green) from the inset region of Figure 1A; (D) tube feet-like structures of the putative water vascular system showing iron distribution; (E) SEM-EDX elemental distribution in the matrix and the fossil. 

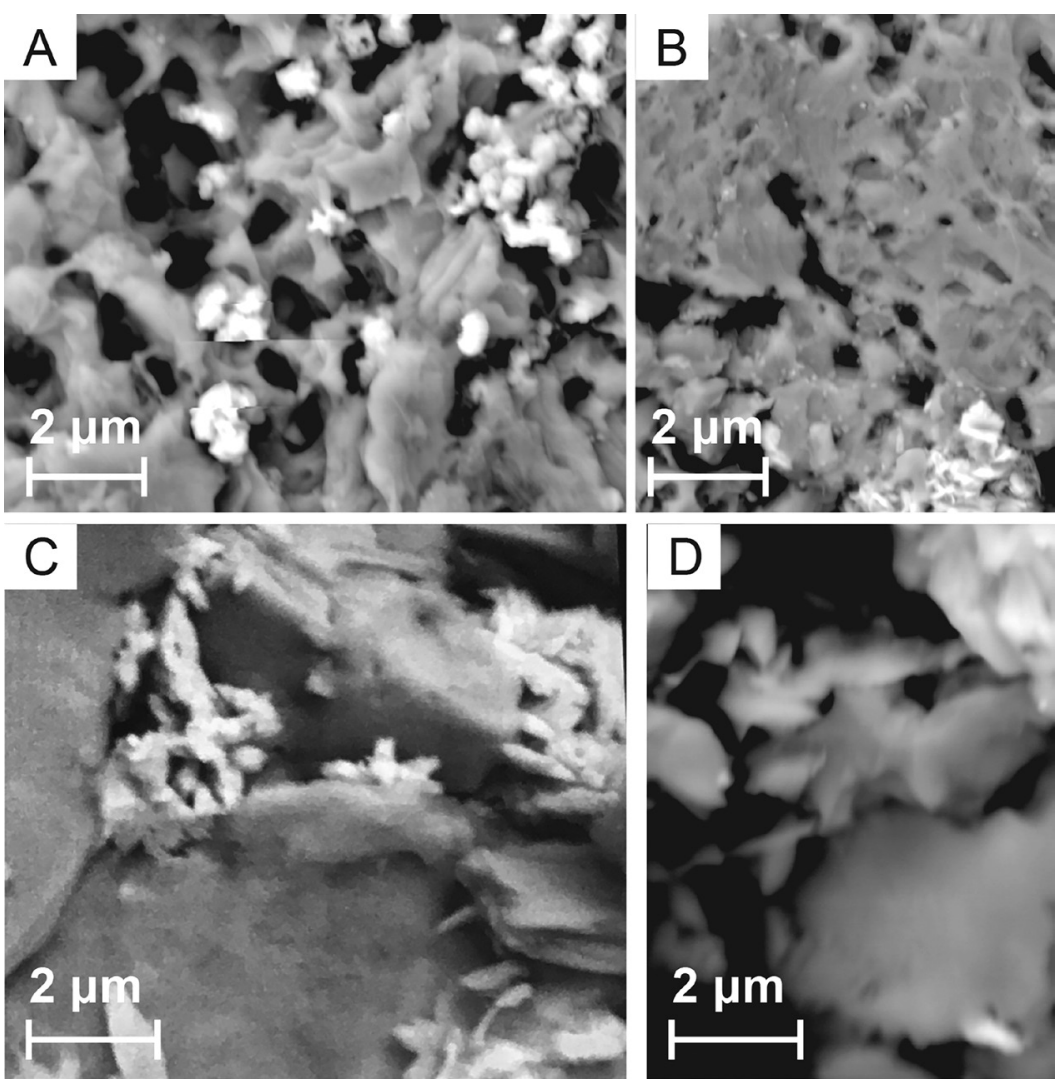

Figure 2: SEM-EDX images showing amorphous shape of particles and iron-rich areas (white regions). in all anatomical parts of the specimen, including skeletal plates (Figure 1C), validates this hypothesis.

The somasteroid specimen shows a totally different elemental distribution in the tube feet-like structures, with the total absence of Fe and the presence of carbon. Carbonaceous films are the main mode of preservation of soft tissues, especially in the Paleozoic era [26]. However, in surface sediments of the Fezouata Shale, carbon is absent from all fossils that have been analyzed $[9,10,12]$. The porous aspect of C-rich deposits in the analyzed specimen is strikingly different from the texture of carbon films in exceptionally preserved biotas [26]. Moreover, in the somasteroid specimen, carbon is not limited to any specific region but appears to fill all micro-depressions of the specimen (Figures 4D-G). Thus, it is very likely that this carbon is the consequence of preparation artifacts: numerous latex casts were made to study the detailed morphology of this specimen. Apparently, latex was not completely removed from small cavities located between skeletal plates, thus mimicking regularly branching tube feet along the ambulacral canal, in the arm region of the analyzed specimen.

\section{Conclusion}

This study confirms the validity of the interpretation as soft parts of the structures identified in stylophoran echinoderms from the Fezouata Shale [12]. However, it also shows that it is probable that reports
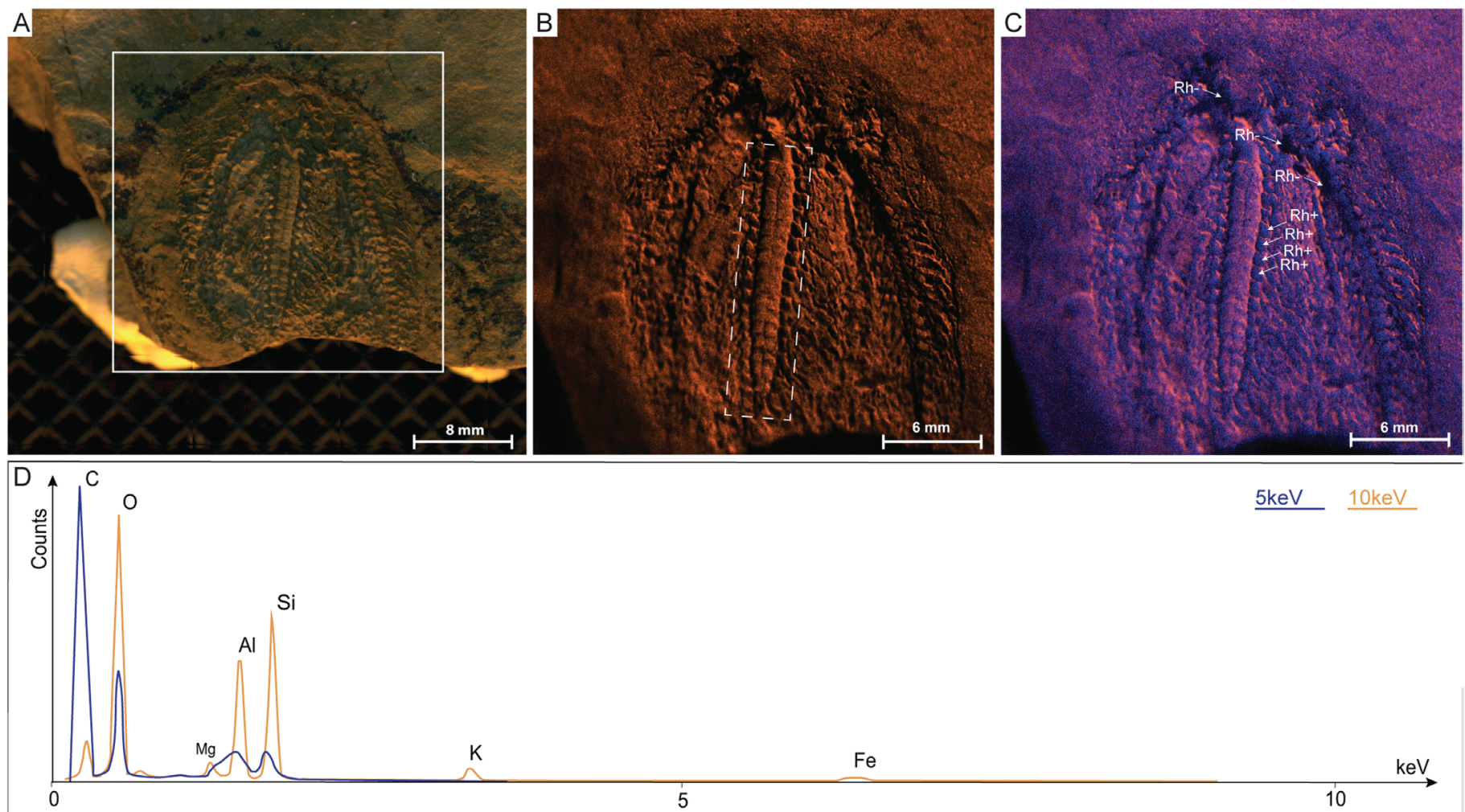

$5 \mathrm{keV}$

$10 \mathrm{keV}$

$\mathrm{Si}$

$\mathrm{K}$

$\mathrm{Fe}$

5

$\stackrel{\mathrm{keV}}{\longrightarrow}$

Figure 3: Analyzed specimen of somasteroid, late Tremadocian, Fezouata Shale, unknown locality, Zagora area, Morocco; UCBL-FSL424962. (A) Photograph of the specimen; (B) XRF, Si distribution; (C) XRF, superposition of Rh (blue) with K; (D) SEM-EDX elemental distribution in the tube feet-like structures. 


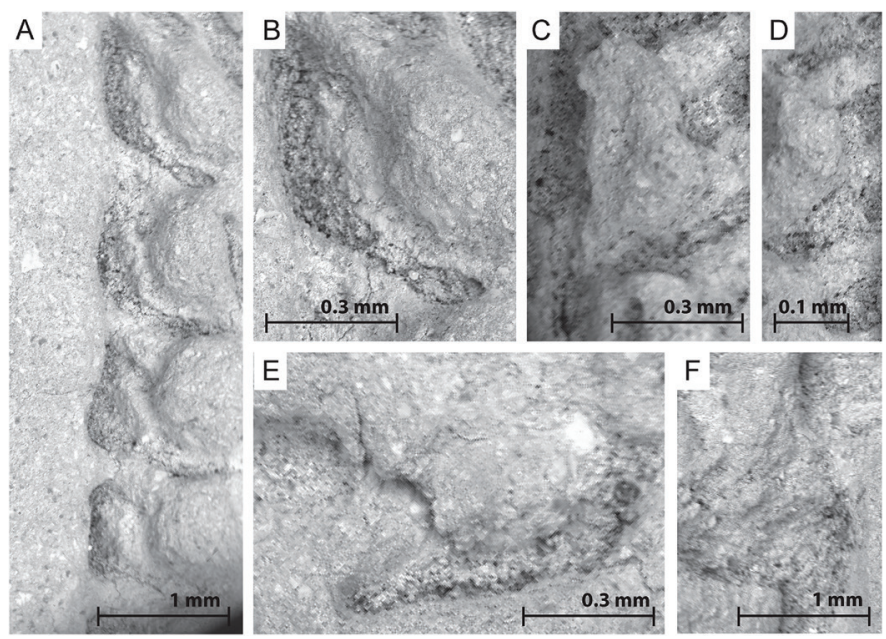

Figure 4: (A-B) Carbon particles (black) in tube feet-like structures of the putative water vascular system, $(\mathrm{C}-\mathrm{F})$ carbon particles found in other random structures showing the same carbon distribution as tube feet-like structures.

of putative soft parts in eocrinoids and somasteroids from the Fezouata Shale $[20,21]$ are either preparation artifacts or the result of recent weathering. In addition, it shows that understanding the history of a specific fossil, from the excavation to preparation, is essential for proper paleontological interpretation, especially when it comes to the description of soft tissues in extinct taxa. These results should be taken into consideration when studying any new fossil, whether it is purchased from a private collector or comes from a museum collection.

\section{Acknowledgements}

This paper is a contribution to the TelluS-INTERRVIE projects "Mécanismes de préservation exceptionnelle dans la Formation des Fezouata" (2018), and "Géochimie d'un Lagerstätte de l'Ordovicien inférieur du Maroc" (2019), all funded by the INSU (Institut National des Sciences de l'Univers, France), CNRS. This paper is also a contribution to the International Geoscience Programme (IGCP) Project 653 - The Onset of the Great Ordovician Biodiversification Event. The authors are grateful to the LABEX Lyon Institute of Origins (ANR-10-LABX-0066) of the Université de Lyon for its financial support within the program "Investissements d'Avenir" (ANR-11-IDEX-0007) of the French government operated by the National Research Agency (ANR). The authors thank Stefan Lalonde and Pierre Sansjofre (Brest University) for assistance during SEM and XRF analyses. The Editor-in-Chief, Bob Price, is thanked for his helpful and constructive remarks.

\section{References}

[1] P Van Roy et al., Nature 465 (2010) 215-18.

[2] P Van Roy et al., J Geol Soc 172 (2015) 541-49.

[3] B Lefebvre et al., Palaeogeogr Palaeoclimatol Palaeoecol 460 (2016) 97-121.

[4] P Van Roy and DEG Briggs, Nature 473 (2011) 510-13.

[5] JC Gutiérrez-Marco et al., Sci Rep 7 (2017) 39728.

[6] J Vinther et al., Nature 451 (2008) 185-88.

[7] M Marti Mus, Palaeogeogr Palaeoclimatol Palaeoecol 460 (2016) 122-29.

[8] J Vinther et al., Nature 542 (2017) 471-74.

[9] ELO Martin et al., Palaeogeogr Palaeoclimatol Palaeoecol 460 (2016) 130-41.

[10] K Kouraïss et al., Palaeogeogr Palaeoclimatol Palaeoecol 508 (2018) 48-58.

[11] B Lefebvre et al., Progr. Abstr. 57 th Pal'Ass Meeting (2013) 44-45.

[12] B Lefebvre et al., Geobios 52 (2018) 27-36.

[13] MD Sutton et al., Proc R Soc B 272 (2005) 1001-06.

[14] DEG Briggs et al., Proc R Soc B 284 (2017) 20171189.

[15] IA Rahman et al., Proc R Soc B 286 (2019) 20182792.

[16] A Glass and DB Blake, Paläont Z 78 (2004) 73-95.

[17] CE Brett et al., Paleont Soc Papers 3 (1997) 147-90.

[18] P Gorzelak and MA Salamon, Palaeogeogr Palaeoclimatol Palaeoecol 386 (2013) 569-74.

[19] F Saleh et al., Earth Planet Sc Lett 529 (2020) 115873.

[20] B Lefebvre et al., Progr. Abstr. 62 ${ }^{\text {nd }}$ Pal'Ass Meeting (2018) 40.

[21] M Nohejlová, Abstr., 5 $5^{\text {th }}$ Int. Palaeont. Congr. (2018) 851.

[22] ELO Martin, Communautés animales du début de l'Ordovicien ( $480 \mathrm{Ma}$ ): etudes qualitatives et quantitatives à partir de sites à preservation exceptionnelle des Fezouata, Maroc, Unpubl. PhD thesis, Lyon, 2016, pp. 1-313.

[23] F Saleh et al., Geology 47 (2018) 103-06.

[24] R Vaucher et al., Sedimentology 64 (2017) 777-807.

[25] SE Gabbott et al., Geology 32 (2004) 901-04.

[26] RR Gaines et al., Geology 36 (2008) 755-58.

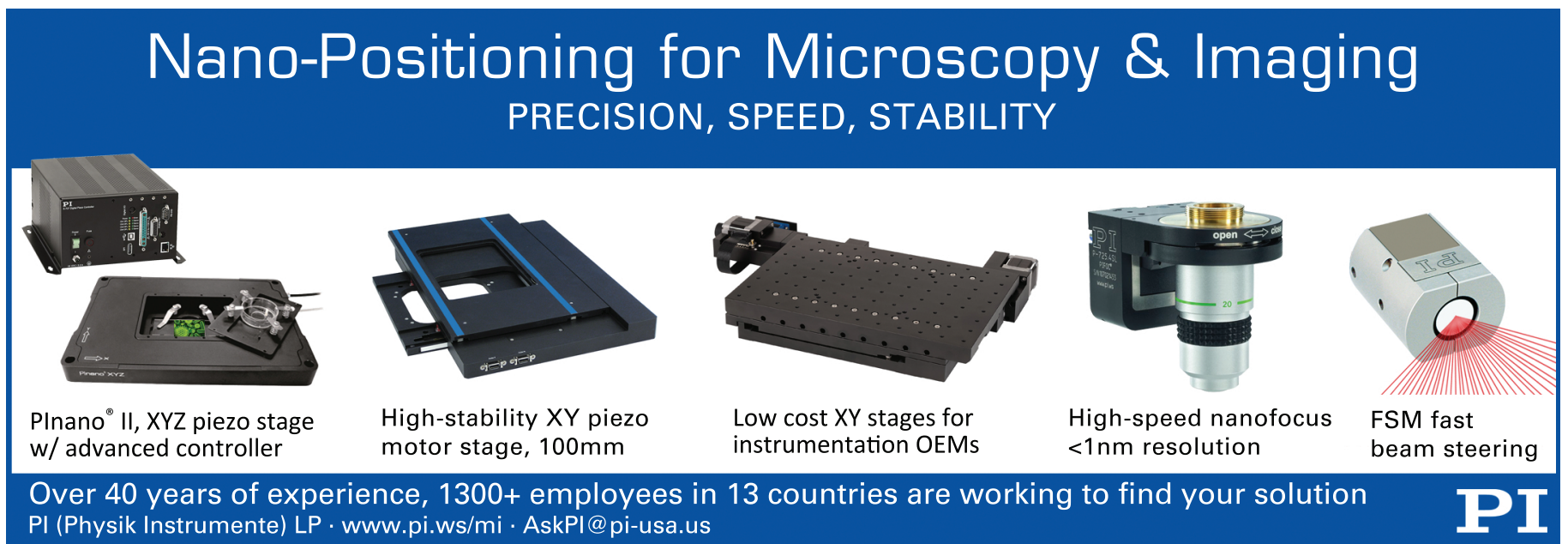



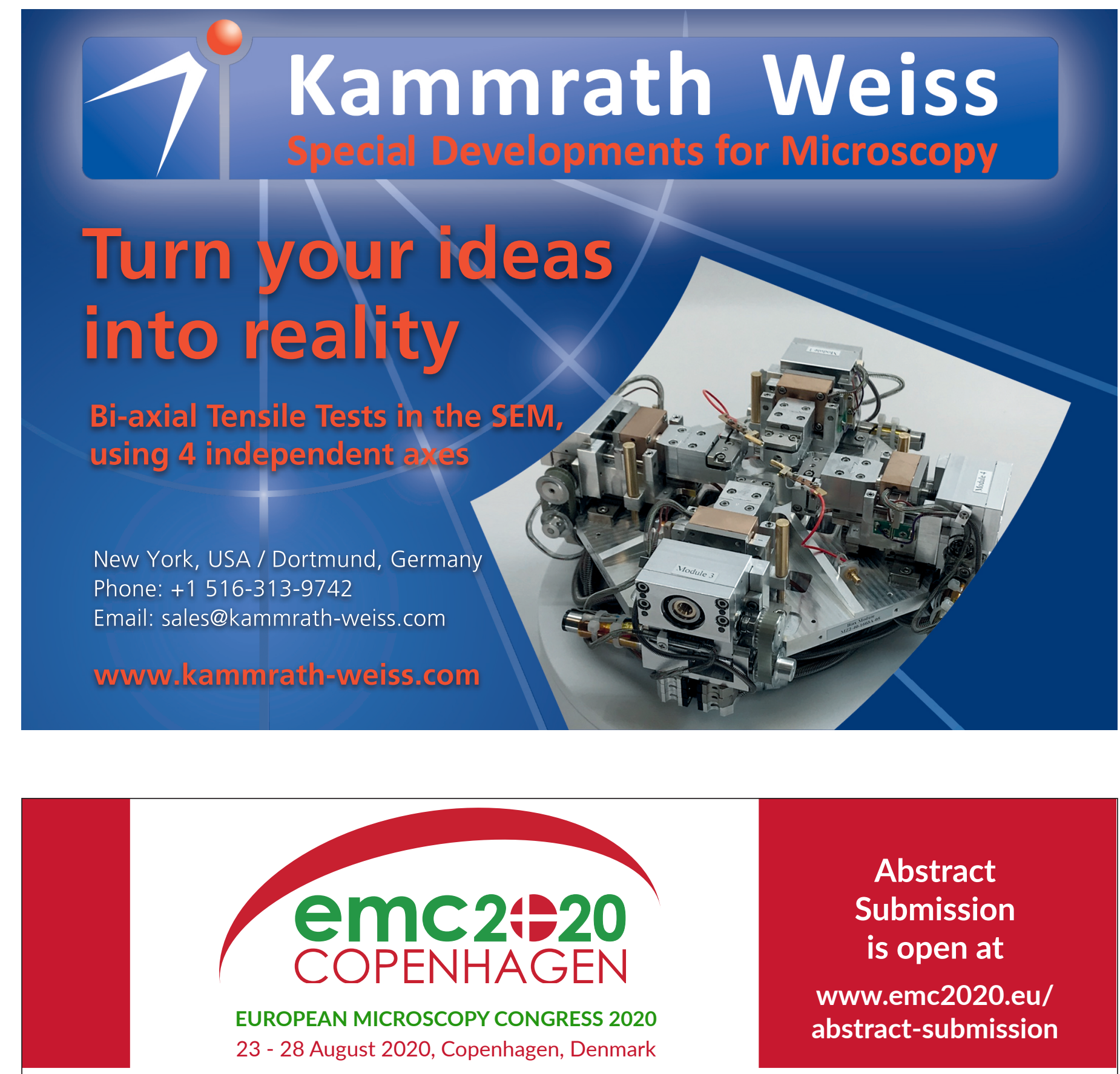

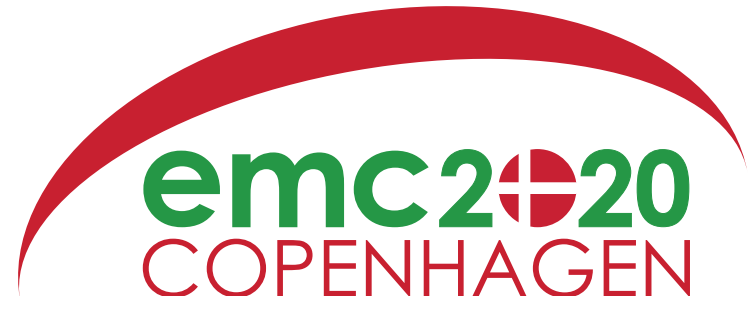

EUROPEAN MICROSCOPY CONGRESS 2020

23 - 28 August 2020, Copenhagen, Denmark

\section{Abstract}

Submission

is open at

www.emc2020.eu/

abstract-submission

\section{Europe's Largest Event Dedicated to Microscopy and Imaging}
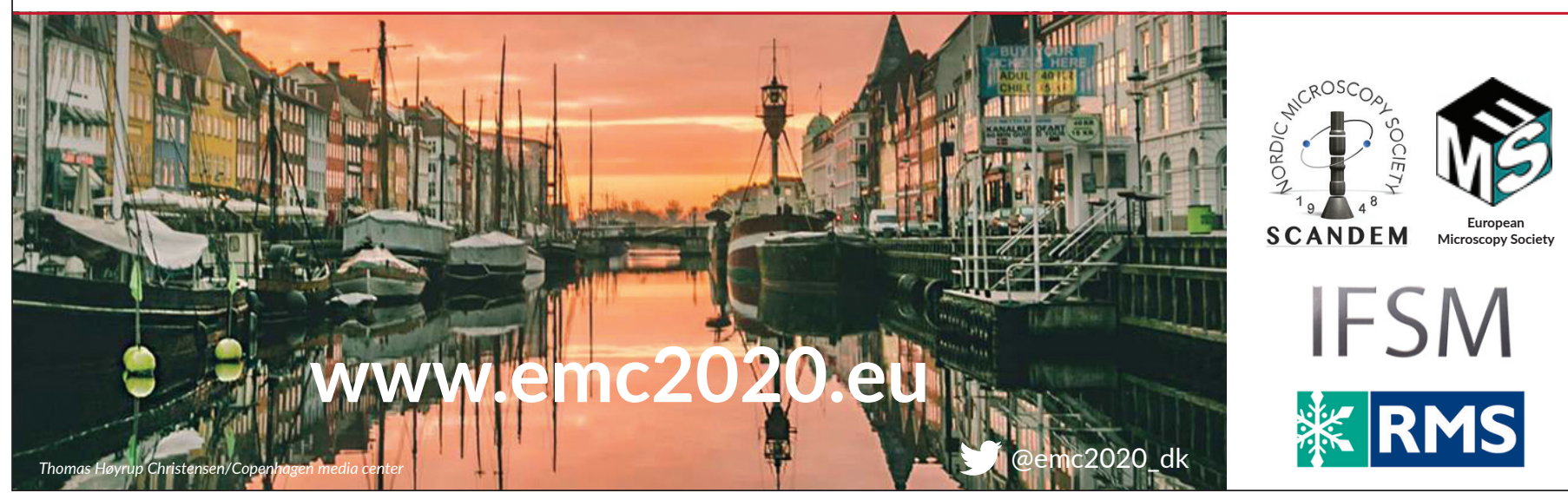

IFSM

篥 RMS 